\title{
DiET OF THE MANATEES (TRICHECHUS MANATUS MANATUS) in Chetumal Bay, Mexico'
}

\author{
Delma Nataly Castelblanco-Martínez², Benjamin Morales-Vela 2,*, \\ Hector A. Hernández-Arana and Janneth Padilla-Saldivar ${ }^{2}$
}

\begin{abstract}
Aвstract: Manatees, as well as other sirenians, are aquatic, opportunistic herbivores. Knowledge of their diet is important to determine habitat requirements. This is the first study of manatee diet in México. Our main objective was to identify the plant species eaten by manatees in Chetumal Bay, and to establish if diet composition varied by climatic season, sex or age class. We compared plant epidermal fragments found in feces with histological descriptions and permanent collections of suspected plants and algae. Thirty-six fecal samples and nine tract digestive content samples (mouth, stomach, and cecum) were examined. We found eight distinct plant items, including seagrasses, freshwater grasses, algae and vascular plants. Halodule wrightii and Thalassia testudinum were found in 41 samples (92\%), and Ruppia sp. was present in $57.8 \%$. Another common item was red mangrove (Rhizophora mangle), found in $66.7 \%$ of samples. Additionally, we report Chara sp. and Najas sp. as part of the West Indian manatee's diet outside of Florida. A multivariate analysis based on a presence/absence triangular matrix and a similarity analysis were used to test differences among samples. Season, sex or age class did not influence diet composition. All species identified are present in Chetumal Bay, suggesting that manatees do not move long distances at sea in search of food. We postulate that consumption of red mangrove by Chetumal Bay manatees may occur as compensation for the scarcity of submersed aquatic plants, which has not been reported for other habitats for this species.
\end{abstract}

Resumen: Los manatíes, así como los demás miembros del orden Sirenia, son herbívoros acuáticos oportunistas. El conocimiento de su dieta es importante para determinar requerimientos de su hábitat. Este es el primer estudio sobre la dieta del manatí en México. El objetivo principal fue identificar las especies vegetales consumidas por manatíes en Bahía de Chetumal, y establecer si la composición de la dieta varía según la estación climática, sexo o clase etaria. Comparamos los fragmentos vegetales encontrados en heces con las descripciones histológicas y colecciones permanentes de especies vegetales probables. Examinamos 36 muestras fecales y nueve contenidos del tracto digestivo (boca, estómago y ciego). Encontramos ocho ítems vegetales, incluyendo pastos marinos, pastos de agua dulce, algas y plantas vasculares. Halodule wrightii y Thalassia testudinum se encontraron en 41 muestras (92\%), y Ruppia sp. se presentó en 57.8\%. Otro ítem común fue el mangle rojo (Rhizophora mangle), encontrado en el $66.7 \%$ de las muestras. Adicionalmente se reportan Chara sp. y Najas sp. como parte de la dieta del manatí de las Indias Occidentales fuera de la Florida. Se usó un análisis multivariado basado en una matriz triangular de presencia/ausencia, así como un análisis de similitud para probar diferencias entre muestras. La estación climática, sexo y clase etaria no influyeron en la composición de la dieta. Todas las especies identificadas se encuentran en la Bahía de Chetumal, mostrando que los manatíes no necesitan desplazarse fuera de ella en busca de alimento. Los resultados permiten asumir que el mangle es un ítem alimenticio importante para la población de manatíes en la Bahía de Chetumal, como compensación a la escasez de plantas acuáticas sumergidas. Esto no ha sido informado para otros hábitats usados por la especie.

KEYwords: herbivory, food, feeding habits, Caribbean Sea, microhistological analysis.

\section{Introduction}

The West Indian manatee (Trichechus manatus), along with related sirenian species, is the only herbivorous aquatic mammal that feeds on a variety of aquatic and semi-aquatic vegetation. Adult specimens are able to ingest 4-9\% of their body weight daily (Bengtson, 1983; Etheridge et al., 1985). Compared to other herbivorous mammals, the manatee is highly efficient at digesting cellulose (Lomolino and Ewel, 1984; Burn, 1986). Some relevant morphological and physiological adaptations, related to its feeding habits, are the unusually large degree of fine motor control of the snout and perioral bristles (Ronald et al., 1978; Marshall et al., 1998; Marshall et al., 2000; Marshall et al., 2003), horizontal tooth replacement (Domning, 1983), and specialized hind-gut fermentation in a large cecum located at the juncture of the large and small intestines (Best, 1981; Burn and Odell, 1987).

Chetumal Bay has been declared a Manatee Protected
Area since 1996, and is part of a wider region in the Caribbean, where T. manatus occurs in high abundance (O'Shea and Salisbury, 1991; Morales-Vela and OliveraGómez, 1994; Morales-Vela, 1997). Some characteristics of Chetumal Bay that favor the occurrence of manatees are protection against wind and currents, availability of freshwater, large shallow areas with submerged and riparian vegetation, and sparse human activity.

There is an important geographical variation in the foraging strategies of manatees, as shown by its diet composition (Reich and Worthy, 2006), due to its wide distribution and large variety of habitats where the manatee occurs (Lefebvre et al., 2001). Information on feeding behavior and diet composition are key aspects for local and regional manatee conservation strategies. Analysis of fecal and digestive contents is a simple, inexpensive and reliable procedure for determining feeding habits of herbivores (Fitzgerald and Waddington, 1979; Garin et al., 2001; Sepúlveda-Palma et al., 2004; Borges and Colares, 2007). The technique has

\footnotetext{
${ }^{1}$ Received on 21 April 2009. Accepted on 7 October 2009. Managed by Karina Acevedo-Whitehouse.

2 El Colegio de la Frontera Sur. Av. Centenario Km. 5.5, CP 77900, Chetumal, Quintana Roo, México.

* Corresponding author, e-mail: bmorales@ecosur.mx.
} 
been used for studying feeding habits of other species of sirenians (Heinsohn and Birch, 1972; Johnstone and Hudston, 1981; Marsh et al., 1982; Ledder, 1986; Hurst and Beck, 1988; Colares and Colares, 2002; Adulyanukosol et al., 2004; Guterres et al., 2008), however, the diet composition of the subspecies T. $m$. manatus has received relatively little attention (Mignucci-Giannoni and Beck, 1998; Borges et al., 2008).

In this study, we analyze fecal and gut contents of manatees from Chetumal Bay to determine diet composition and plant selection by season, sex and age-class.

\section{Methods}

\section{Study area}

Chetumal Bay $\left(17^{\circ} 52^{\prime}-18^{\circ} 50^{\prime} \mathrm{N}, 87^{\circ} 50^{\prime}-88^{\circ} 25^{\prime} \mathrm{W}\right)$, is a large shallow estuary of $\sim 2450 \mathrm{~km}^{2}$ with an average depth of $3.2 \mathrm{~m}$, shared by Mexico and Belize. This coastal system of karstic origin and low productivity has variable marine influence, permanent freshwater inputs through the Rio Hondo, New River, and continuous underground runoff (Carrillo et al., 2009; Castellanos-Osorio, 2009). Intraannual climatic variability is driven by dry, rainy and cold front seasons with occurrence of tropical storms and hurricanes in a larger temporal scale (Carrillo et al., 2009). Submerged vegetation is formed by Thalassia testudinum, Halodule wrightii, Ruppia sp., Najas sp., several macroalgae species (Quan-Young et al., 2006) and four species of mangroves (Rhizophora mangle, Laguncularia racemosa, Conocarpus erectus and Avicennia germinans).

\section{Microhistological analyses}

One useful technique to determine diet is based on direct comparison of plant fragments present in feces and gut contents with voucher slide specimens or illustrations in reference collections (Hurst and Beck, 1988; Rosito and Marchezan, 2003). We obtained samples from wild manatees that had been captured for health monitoring, from dead animals during necropsies, or from opportunistic collection of feces found floating in the bay (Opportunistic samples are denoted as "unknown" in Table 1). All samples were preserved in FAA (85\% ethyl alcohol, $10 \%$ formalin at $10 \%, 5 \%$ glacial acetic acid) (Colares, 1990).

Samples were collected from 2004 to 2007, and included 36 fecal samples and nine from gut content samples (one collected from the cecum, two from the stomach, and six from the mouth) (Table 1). Each sample was homogenized and filtered through a $425 \mu \mathrm{m}$ sieve. A subsample from the material retained on the sieve was placed in a Petri dish, cleared with 20 drops of sodium hypoclorite to help microstructure observation of plant debris. An aliquot was placed on a glass slide with a grid of 36 fields. Five glass slides were observed under the microscope at 10X, 40X and, if necessary, 100X magnification. For each field of the glass slide the plant fragments were identified up to species level using the guides proposed by Hurst and Beck (1988) and Orozco-
Meyer (1995) and a reference collection of plant tissues from Chetumal Bay. Species identification was made considering size and shape of epidermal cells, presence and distribution of tannin and silica deposits, distribution and types of stomata, and distribution, types and sizes of trichomes and veins (Heinsohn and Birch, 1972; Colares and Colares, 2002). All mouth content samples were observed under a stereoscopic microscope. Key aspects for plant species identification were the leaf apex, enervation, hardness, edge ornaments, and the size, shape and arrangement of epidermal cells (Johnstone and Hudston, 1981).

\section{Data analysis}

The analysis was designed a priori in order to evaluate differences in diet composition related to sex, age and season. Manatees $\leq 175 \mathrm{~cm}$ were considered calves that were nutritionally dependent on females (O'Shea et al., 1985), while the rest of the organisms individuals were treated as adults. A multivariate statistical Analysis of Similarity (ANOSIM), based on a presence/absence triangular similarity matrix of plant items was used to test for differences against and among different levels of main factors (sex, age and season). A Bray-Curtis index of similarity was used to construct the triangular matrix and a graphical interface by means of non-metric MDS was used to show any patterns of similarity in the data (Clarke and Warwick, 1994).

\section{Results}

Eight plant items were recorded overall, of which four were identified to species level, two to genus level and the other two named as species 1 and species 2. Grass rhizome was found in all samples. However, identification to the genus or species level was not possible and we therefore excluded this item from the analysis. The numbers of plant items found per sample ranged from two to seven, but three to four items were predominant in most samples (Figure 1). Mouth samples only contained one or two plant species. Stomach samples contained three to five species, whereas in cecum samples, four species were identified.

The manatee diet from Chetumal Bay was mainly composed of phanerogams (Table 2). Seagrasses, such as Halodule wrightii and Thalassia testudinum, were present in $91 \%$ of the samples, whereas Ruppia sp. was present in $58 \%$ of the samples. We found typical leaf tissue and H-shaped trichosclereids of Rhizophora mangle in 30 fecal samples, but none in digestive content samples. Chara sp. was present in two stomach samples, but only in $11 \%$ of the fecal samples. Najas sp. was present in $9 \%$ of the samples including feces, stomach and cecum contents. Two unidentified plant species were recorded, (species 1 and 2) in $24 \%$ and $16 \%$ of samples, respectively. Statistical analyses showed that there were no effects on diet composition related to season, sex or age class. 
Table 1. Fecal and digestive content samples used for diet determination of manatees in Chetumal Bay.

\begin{tabular}{|c|c|c|c|c|c|c|c|c|}
\hline $\begin{array}{l}\text { SAMPLE } \\
\text { ID }\end{array}$ & $\begin{array}{c}\text { MANATEE } \\
\text { ID }\end{array}$ & $\begin{array}{l}\text { INDIVIDUAL } \\
\text { STATE }\end{array}$ & $\overline{\text { TYPE }}$ & $\overline{\text { DATE }}$ & SEASON & $\overline{S \text { SEX }}$ & $\begin{array}{c}\text { LENGTH } \\
(\mathrm{cm})\end{array}$ & $\begin{array}{c}\text { AGE } \\
\text { CLASS } \\
\end{array}$ \\
\hline 1 & ב BCH01 & Alive & Fecal & $24 / 05 / 2004$ & Dry & 오 & 275 & Adult \\
\hline 2 & ВCH02 & Alive & Fecal & $25 / 05 / 2004$ & Dry & 오 & 225 & Adult \\
\hline 3 & ВCH04 & Alive & Fecal & $25 / 05 / 2004$ & Dry & 우 & 283 & Adult \\
\hline 4 & ВCH06 & Alive & Fecal & $28 / 05 / 2004$ & Dry & 6 & 227 & Adult \\
\hline 5 & ВСH07 & Alive & Fecal & $28 / 05 / 2004$ & Dry & 웅 & 275 & Adult \\
\hline 6 & BCH12 & Alive & Fecal & $03 / 10 / 2004$ & Cold Fronts & $\stackrel{+}{+}$ & 298 & Adult \\
\hline 7 & BCH13 & Alive & Fecal & $04 / 10 / 2004$ & Cold Fronts & 0 & 270 & Adult \\
\hline 8 & BCH16 & Alive & Fecal & $12 / 10 / 2004$ & Cold Fronts & 웅 & 283 & Adult \\
\hline 9 & ВСН30 & Alive & Fecal & $08 / 09 / 2005$ & Rainy & 우 & 253 & Adult \\
\hline 10 & ВСН32 & Alive & Fecal & $25 / 10 / 2005$ & Rainy & d & 206 & Adult \\
\hline 11 & ВСН34 & Alive & Fecal & $26 / 03 / 2006$ & Dry & 0 & 165 & Calf \\
\hline 12 & ВСН35 & Alive & Fecal & $26 / 06 / 2006$ & Rainy & 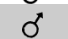 & 267 & Adult \\
\hline 13 & ВСH36 & Alive & Fecal & $27 / 06 / 2006$ & Rainy & 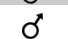 & 292 & Adult \\
\hline 14 & ВСН37 & Alive & Fecal & $28 / 03 / 2006$ & Dry & 오 & 196 & Calf \\
\hline 15 & ВСН38 & Alive & Fecal & $29 / 03 / 2006$ & Dry & c) & 228 & Adult \\
\hline 16 & BCH40 & Alive & Fecal & $11 / 10 / 2006$ & Rainy & O & 268 & Adult \\
\hline 17 & BCH41 & Alive & Fecal & $12 / 10 / 2006$ & Rainy & c) & 233 & Adult \\
\hline 18 & BCH42 & Alive & Fecal & $13 / 10 / 2006$ & Rainy & 오 & 286 & Adult \\
\hline 19 & BCH43 & Alive & Fecal & $14 / 05 / 2006$ & Dry & o & 282 & Adult \\
\hline 20 & BCH46 & Alive & Fecal & $19 / 03 / 2007$ & Dry & 오 & 280 & Adult \\
\hline 21 & ВCH47 & Alive & Fecal & $20 / 03 / 2007$ & Dry & c) & 304 & Adult \\
\hline 22 & ВСH48 & Alive & Fecal & $22 / 03 / 2007$ & Dry & 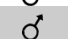 & 268 & Adult \\
\hline 23 & BCH49 & Alive & Fecal & $22 / 03 / 2007$ & Dry & 0 & 250 & Adult \\
\hline 24 & BCH50 & Alive & Fecal & $23 / 03 / 2007$ & Dry & 웅 & 177 & Calf \\
\hline 25 & BCH52 & Alive & Fecal & $18 / 05 / 2007$ & Dry & 우 & 312 & Adult \\
\hline 26 & ВCH53 & Alive & Fecal & $24 / 05 / 2007$ & Dry & $\stackrel{+}{+}$ & 285 & Adult \\
\hline 27 & TQR02 & Alive & Fecal & 17/11/1994 & Cold Fronts & -- & --- & Adult \\
\hline 28 & --- & Unknown & Fecal & 06/02/1995 & Cold Fronts & --- & --- & Adult \\
\hline 29 & --- & Unknown & Fecal & 20/02/1995 & Cold Fronts & --- & --- & --- \\
\hline 30 & --- & Unknown & Fecal & 20/02/1995 & Cold Fronts & --- & --- & --- \\
\hline 31 & --- & Alive & Fecal & 03/05/1995 & Dry & --- & --- & --- \\
\hline 32 & --- & Unknown & Fecal & 05/1998 & Dry & --- & --- & --- \\
\hline 33 & --- & Unknown & Fecal & 02/09/1995 & Rainy & --- & --- & --- \\
\hline 34 & --- & Unknown & Fecal & $20 / 10 / 1998$ & Cold Fronts & --- & --- & --- \\
\hline 35 & --- & Unknown & Fecal & $23 / 04 / 2000$ & Dry & --- & --- & --- \\
\hline 36 & BCH52 & Alive & Fecal & $13 / 02 / 2001$ & Cold Fronts & 0 & --- & Calf \\
\hline 37 & --- & Death & Cecum & $11 / 03 / 2002$ & Dry & 0 & 282 & Adult \\
\hline 38 & --- & Death & Stomach & $30 / 01 / 2001$ & Cold Fronts & q & 158 & Calf \\
\hline 39 & --- & Death & Stomach & $02 / 2004$ & Cold Fronts & 우 & --- & --- \\
\hline 40 & --- & Death & Mouth & $18 / 05 / 2007$ & Dry & q & 312 & Adult \\
\hline 41 & --- & Alive & Mouth & $29 / 04 / 2004$ & Dry & c) & --- & Adult \\
\hline 42 & ВCH02 & Alive & Mouth & $25 / 05 / 2004$ & Dry & q & 225 & Adult \\
\hline 43 & --- & Alive & Mouth & $05 / 05 / 2004$ & Dry & -- & --- & --- \\
\hline 44 & ВСH07 & Alive & Mouth & $28 / 05 / 2004$ & Dry & 우 & 275 & Adult \\
\hline 45 & BCH06 & Alive & Mouth & $28 / 05 / 2004$ & Dry & 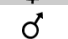 & 227 & Adult \\
\hline
\end{tabular}

\section{Discussion}

Although determination of mouth contents is a relatively easy task, only two plant species were identified in mouth content samples because manatees tend to graze in submerged beds of dominant seagrasses (Campbell and Irvine, 1977; Hartman, 1979; Packard, 1984; Lefebvre and Powell, 1990; Provancha and Hall, 1991) similar to dugongs (Johnstone and Hudston, 1981). Manatee digestive passage times range from four to ten days (Larkin et al., 2007), therefore, fecal material is likely to reflect weekly individual feeding habits. In accordance with this idea, and in contrast to what was observed in mouth, stomach and cecum contents, fecal samples contained all of the listed species. The number of listed species is in correspondence with the general diversity of submerged vegetation in Chetumal Bay (EspinozaAvalos, 1996), thus we consider our sample size 'representative' and the histological analyses adequate for preliminary identification of the diet composition of manatees in Chetumal Bay.

The study of herbivorous diet using histological analyses of feces does not allow the determination of the relevance of each item, since each plant undergoes a particular digestive process depending on its physical and chemical features (Fitzgerald and Waddington, 1979). Thus, depending on the plant's resistance to digestion, the 


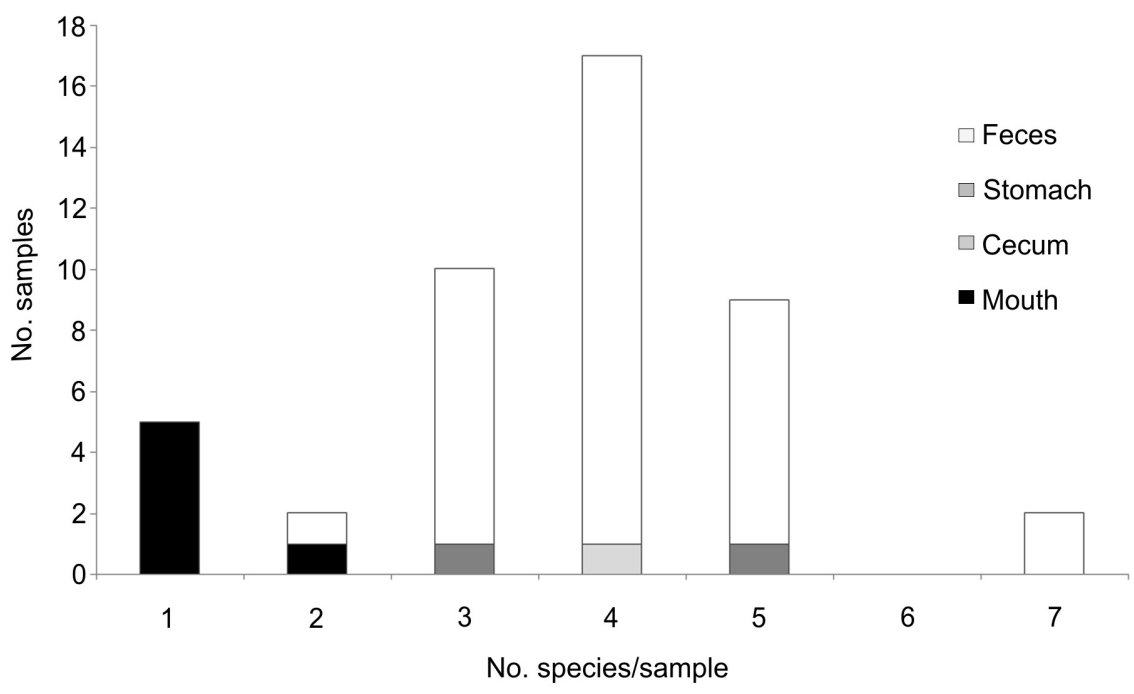

Figure 1. Richness of plant species found in fecal and digestive content samples of manatees from Chetumal Bay

Table 2. Number and percentage of diet items of manatees from Chetumal Bay.

\begin{tabular}{lcrcccccc}
\hline \hline & $\mathrm{Tt}$ & $\mathrm{Hw}$ & $\mathrm{Rhm}$ & $\mathrm{Rum}$ & Species 1 & Species 2 & $\mathrm{Ch}$ & $\mathrm{N}$ \\
\hline \hline Feces (36) & 36 & 35 & 30 & 22 & 11 & 7 & 4 & 2 \\
Cecum (1) & 1 & 1 & 0 & 1 & 0 & 0 & 0 & 1 \\
\hline Stomach (2) & 2 & 1 & 0 & 2 & 0 & 0 & 2 & 1 \\
Mouth (6) & 2 & 4 & 0 & 1 & 0 & 0 & 0 & 0 \\
\hline Total (45) & 41 & 41 & 30 & 26 & 11 & 7 & 6 & 4 \\
Percent (\%) & 91.1 & 91.1 & 66.7 & 57.8 & 24.4 & 15.6 & 13.3 & 8.9 \\
\hline \hline
\end{tabular}

$T t=$ Thalassia testudinum, Hw= Halodule wrightii, Rhm= Rhizophora mangle, Rum= Ruppia maritima, $C h=$ Chara sp., $N=$ Najas sp. Fragments of seagrass rhizomes are not included as they were found in all samples. The number of samples is indicated in brackets.

amount of plant fragments in feces would vary leading to an underestimation of less resistant species, such as algae (Garin et al., 2001); therefore, quantitative comparisons between items is not reliable.

The number of items per sample ranged between one and seven, similar to what has been found in other studies using the same technique: 2-8 for Trichechus manatus manatus in Puerto Rico (Mignucci-Giannoni and Beck, 1998), 2-9 for T. m. m. in Brazil (Borges et al., 2008), 2-10 for T. m. latirostris in Florida (Ledder, 1986), 1-7 for T. inunguis (Colares and Colares, 2002), and 1-5 for Dugong dugon (Heinsohn and Birch, 1972).

Mignucci-Giannoni and Beck (1998) recorded eight plant species in the gut content of manatees from Puerto Rico. Species common between our study and this previous one were Thalassia testudinum, Halodule wrightii and Rhizophora mangle. Additionally, for the manatee from Puerto Rico, Syringodium filiforme, Ulva lactuca and Caulerpa prolifera were also recorded (MignucciGiannoni and Beck, 1998). Those three species, although present in the neighboring reef lagoon, have not been found in the estuarine system of Chetumal Bay (Espinoza-Avalos, 1996). Studies in northeastern Brazil have reported up to 21 plant items, including phanerogams, green, red and brown algae in gut content of manatees, despite a smaller sample size (Borges et al., 2008). This result clearly reflects the greater diversity of habitats and plant species available for manatees on the Brazilian coast. A large variety of food items have been reported also for sirenians inhabiting high biodiversity areas, such as dugong (Marsh et al., 1982) and Amazonian manatee (Colares and Colares, 2002). From the 25 plant species recorded as food items for the Caribbean manatee, only $H$. wrightii and $R$. mangle were common to Puerto Rico, Brazil and México (Table 3).

As found in other studies (Ledder, 1986; MignucciGiannoni and Beck, 1998) seagrasses were the plant most frequently consumed by manatees in Chetumal Bay. Algae species such as Batophora sp. and Chara sp, are common in Chetumal Bay and in the channel 
system of Laguna Guerrero, and are a potentially important food resource for manatees. Also, manatees have been observed consuming Batophora sp. However, only Chara sp. was found in low proportion in our content samples. Algae consumption by manatees has been widely documented (Lewis et al., 1984; Mignucci-Giannoni and Beck, 1998; Borges et al., 2008), but it seems to be an incidental ingestion (Reynolds III and Rommel, 1996) and apparently algae is not a significant part of the manatees' diet (Snipes, 1984). Manatees have a slow digestive rate and efficient breakdown of fibrous plant material (Reynolds III and Rommel, 1996) by means of microbial degradations (Snipes, 1984). As a selective feeder, they might prefer to feed on vascular plants that are rich in cellulose.

It is known that manatees consume mangroves. In our study, mangrove was recorded in $68 \%$ of the analyzed samples, whereas it was found in two of eight stomach samples from Puerto Rico (Mignucci-Giannoni and Beck, 1998). In northeastern Brazil, mangrove was reported in $23 \%$ of the analyzed samples (Borges et al., 2008).

Sirenians are generalist herbivores feeding on submerged vegetation in a variety of environments and depths. They are also opportunistic feeders because they consume vegetation with the highest spatial cover within the inhabited area (Heinsohn and Birch, 1972; Domning, 1980; Johnstone and Hudston, 1981; Marsh et al., 1982;

Table 3. Diet composition of Trichechus manatus manatus, determined by histological analysis in Puerto Rico (Mignucci-Giannoni and Beck, 1998), Brazil (Borges et al., 2008) and Chetumal Bay, México.

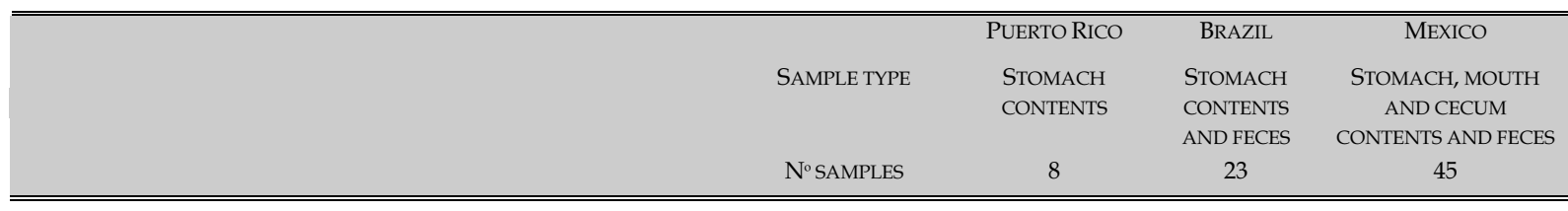

$\begin{array}{llll} & & \\ \text { CLASS } & \text { ORDER } & \text { FAMILY } & \text { SPECIES }\end{array}$

\begin{tabular}{|c|c|c|c|c|c|c|c|}
\hline \multirow{7}{*}{ 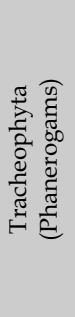 } & \multirow[t]{7}{*}{ Magnoliopsida } & \multirow[t]{2}{*}{ Alismatales } & \multirow[t]{2}{*}{ Cymodoceaceae } & \multirow{2}{*}{$\begin{array}{l}\text { Halodule wrightii } \\
\text { Syringodium } \\
\text { filiforme }\end{array}$} & \multirow{2}{*}{$\begin{array}{l}+ \\
+\end{array}$} & \multirow[t]{2}{*}{+} & \multirow[t]{3}{*}{+} \\
\hline & & & & & & & \\
\hline & & Alismatales & Hydrocharitaceae & Halophila sp. & & + & \\
\hline & & & & Najas sp. & & & + \\
\hline & & & & $\begin{array}{l}\text { Thalassia } \\
\text { testudinum }\end{array}$ & + & & + \\
\hline & & Alismatales & Ruppiaceae & Ruppia maritima & & & + \\
\hline & & Malpighiales & Rhizophoraceae & Rhizophora mangle & $+^{*}$ & $+^{*}$ & + \\
\hline \multirow{7}{*}{ 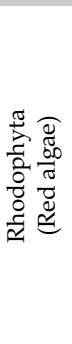 } & \multirow[t]{7}{*}{ Florideophyceae } & Ceramiales & Rhodomelaceae & $\begin{array}{l}\text { Bryothamnion } \\
\text { seaforthii }\end{array}$ & & + & \\
\hline & & & & $\begin{array}{l}\text { Osmundaria } \\
\text { obtusiloba }\end{array}$ & & + & \\
\hline & & Cryptonemiales & Halymeniaceae & $\begin{array}{l}\text { Cryptonemia } \\
\text { crenulata }\end{array}$ & & + & \\
\hline & & Gelidiales & Gelidiaceae & Gelidium sp. & & + & \\
\hline & & Gelidiales & Gelidiellaceae & Gelidiella acerosa & & + & \\
\hline & & Gigartinales & Hypneaceae & Hypnea musciformis & & + & \\
\hline & & Gracilariales & Gracilariaceae & Gracilaria sp. & & + & \\
\hline \multirow{6}{*}{ 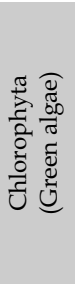 } & \multirow[t]{4}{*}{ Bryopsidophyceae } & \multirow[t]{4}{*}{ Bryopsidales } & \multirow[t]{4}{*}{ Caulerpaceae } & $\begin{array}{l}\text { Caulerpa } \\
\text { cupressoides }\end{array}$ & & + & \\
\hline & & & & Caulerpa mexicana & & + & \\
\hline & & & & Caulerpa prolifera & + & + & \\
\hline & & & & $\begin{array}{l}\text { Caulerpa } \\
\text { sertularioides }\end{array}$ & & + & \\
\hline & \multirow[t]{2}{*}{ Ulvophyceae } & Cladophorales & Anadyomenaceae & Anadyomene stellata & & + & \\
\hline & & Ulvales & Ulvaceae & Ulva lactuca & + & & \\
\hline \multirow{5}{*}{ 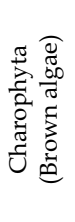 } & Charophyceae & Charales & Characeae & Chara sp. & & & + \\
\hline & \multirow[t]{4}{*}{ Phaeophyceae } & Dyctyotales & Dictyotaceae & Dictyopteris sp. & & + & \\
\hline & & & & Dictyota sp. & & + & \\
\hline & & & & Padina gymnospora & & + & \\
\hline & & Fucales & Sargassaceae & Sargassum sp. & & + & \\
\hline
\end{tabular}

$\left(^{*}\right)$ Authors report 'mangrove' but did not specify the species. 
Ledder, 1986; Mignucci-Giannoni and Beck, 1998; Borges et al., 2008). Seagrass biomass in Chetumal Bay is low compared to other systems where this species occurs (Espinoza-Avalos et al., 2009). Additionally, the number of macroalgae in Chetumal Bay is low, reflecting that this system is relatively poor in submerged vegetation (QuanYoung et al., 2006). Thus, our results suggest that mangroves are a food supply for the local population of manatees. H-shaped, brilliant idioblasts were found in fecal samples from Chetumal Bay. This kind of structures are especially abundant in aerial roots and seedling hypocotyls of red mangrove (Tomlinson and Cox, 2000). Also, fragments of mangrove leaves tissue were registered. This suggests than manatees explore different parts of mangrove plants.

All the plant species recorded in this study are distributed within Chetumal Bay (Espinoza-Avalos, 1996). The absence of strict marine plants (i.e. Siryngodium sp.) in the manatees' diet might suggest that the local population of Chetumal Bay do not travel out to sea to feed, in contrast to what Reich and Worthy (2006) reported for the Florida manatee, which consumes mainly estuarine and marine grasses and algae.

This study did not find an association between climate or season and diet composition, similar to what Preen (1995) reported for dugong. However, Amazonian manatees are known to modify their diet throughout the year in response to changes in water levels which control the amount and type of vegetation available (Best, 1983; Colares et al., 2000). It appears that the Chetumal Bay manatee population's feeding habits are not influenced by yearly variations in submerged vegetation growth and availability.

Seagrasses, freshwater grasses and mangrove areas are threatened by both natural phenomena and humanrelated activities. Aquatic grasses, the main component of manatee's diet, are widely distributed but scarce in Chetumal Bay. This is probably due to local substrate instability, which reduces the light penetration and limits the seagrasses beds proliferation (EspinozaAvalos et al., 2009). Storm-water runoff and hurricanes can have huge consequences for the longterm persistence of the mangroves and seagrasses communities (Mangel and Tier, 1994). These phenomena also have a relevant effect on the bottom structure and therefore, on plant community's composition. Stochastic events, especially if severe or frequent, are a source of direct and indirect mortality of sirenians (Spain and Heinsohn, 1973; Heinsohn and Spain, 1974; Marsh et al., 1986; Marsh, 1989; Preen and Marsh, 1995; Langtimm and Beck, 2003; Gales et al., 2004; Langtimm et al., 2006). If the food base is degraded or destroyed, manatees could change their feeding habits (Spain and Heinsohn, 1973) or voluntarily leave, as has been documented with dugongs (Heinsohn and Spain, 1974; Preen and Marsh, 1995). Mortality and emigration evidently have important implications for the recovery and persistence of the local manatee population (Langtimm et al., 2006).
At the other hand, development of coastal areas for residential and commercial purposes, upland agricultural activities, increased wastewater discharge, chemical contamination and aquatic recreational and commercial activities decrease water quality and lead to a reduction in the available foraging habitat for manatees (Smith, 1993). In Chetumal Bay, minimization of human-related threats to aquatic and sub-aquatic vegetation should be a priority for the permanence of the manatee population.

\section{Acknowledgements}

This research was funded by CONACyT (Project SEMARNAT-CONACyT 2002-C01-1128). D.N.C-M was supported by a CONACyT doctoral scholarship. Additional support was received from Dolphin Discovery Group and Sirenian International Inc. We thank Rafael Estrada-Anaya, Gerardo Rodríguez-Martínez, Marco Benítez-García and Daniel Robelo-Martínez for their collaboration in manatee captures and sample collection. We especially thank Cathy Beck for the meaningful help in the identification of some vegetal fragments. Antonio Mignucci-Giannoni, John Reynolds, Karina AcevedoWhitehouse and one anonymous referee provided useful comments to improve the manuscript.

\section{References}

Adulyanukosol, K., Boukaew, P. and Prasitthipornkul, A. (2004) Analysis of stomach contents of dugongs (Dugong dugon) from Gulf of Thailand. Page 45 in International Symposium on SEASTAR2000 and Bio-logging Science, Bangkok, Thailand.

Bengtson, J.L. (1983) Estimating food consumption of freeranging manatees in Florida. Journal of Wildlife Management 47(4): 1186-1192

BEST, R.C. (1981) Foods and feeding habits of wild and captive Sirenia. Mammal Review 11(1): 3-29.

BEST, R.C. (1983) Apparent dry-season fasting in Amazonian manatees (Mammalia, Sirenia). Biotropica 15(1): 61-64.

Borges, J.C.G., Araúto, P.G., Anzolin, D.G. and de Miranda, G.E.C. (2008) Identificação de itens alimentares constituintes da dieta dos peixes-boi marinhos (Trichechus manatus) na região Nordeste do Brasil. Biotemas 21(2): 77-81.

Borges, L.D.V. and Colares, I.G. (2007) Feeding habits of capybaras (Hydrochoerus hydrochaeris, Linnaeus 1766), in the Ecological Reserve of Taim (ESEC - Taim) - South of Brazil. Brazilian Archives of Biology and Technology 50(3): 409-416.

BurN, D.M. (1986) The digestive strategy and efficiency of the West Indian manatee, Trichechus manatus. Comparative Biochemistry and Physiology Part A: Physiology 85(1): 139-142.

Burn, D.M. AND Odell, D.K. (1987) Volatile fatty acid concentrations in the digestive tract of the West Indian manatee, Trichechus manatus. Comparative Biochemistry and Physiology Part B: Biochemistry and Molecular Biology 88(1): 47-49.

CAmpbell, H.W. And Irvine, B. (1977) Feeding ecology of the West Indian manatee Trichechus manatus Linnaeus. Aquaculture 12(3): 249-251. 
Carrillo, L., Palacios-Hernández, E., Ramírez, A.M. and Morales-Vela, B. (2009) Características hidrometeorológicas y batimétricas. Pages 12-20 in Espinoza-Avalos, J., Islebe, G. and Hernández-Arana, H. (Eds) El sistema ecológico de la Bahía de Chetumal / Corozal: costa occidental del Mar Caribe. El Colegio de la Frontera Sur, Chetumal, Quintana Roo, México.

Castellanos-Osorio, I. (2009) Estudios de zooplancton: Logros y retos. Pages 61-68 in J. Espinoza-Avalos, J., Islebe, G. AND Hernández-Arana, H. (Eds) El sistema ecológico de la Bahía de Chetumal / Corozal: costa occidental del Mar Caribe. El Colegio de la Frontera Sur, Chetumal, Quintana Roo, México.

Clarke, K.R. AND WARWICK, R.M. (1994) Change in marine communities: An approach to statistical analysis and interpretation. Bourne Press Limited, Bournemouth, UK.

Colares, E.P., Colares, I.G., Bianchini, A. and Santos, E.A. (2000) Seasonal variations in blood parameters of the Amazonian manatee, Trichechus inunguis. Brazilian Archives of Biology and Technology 43(2): 165-171.

Colares, I.G. (1990) Hábitos alimentares do peixe-boi da Amazônia (Trichechus inunguis, Mammalia: Sirenia). M.Sc. Thesis. INPA/ FUA. Manaus, Brasil.

Colares, I.G. AND Colares, E.P. (2002) Food plants eaten by Amazonian manatees (Trichechus inunguis, Mammalia: Sirenia). Brazilian Archives of Biology and Technology 45(1): 67-72.

Domning, D.P. (1980) Feeding position preference in manatees (Trichechus). Journal of Mammalogy 61(3): 544-547.

Domning, D.P. (1983) Marching teeth of the manatee. Natural History 92(5): 8-12.

Espinoza-Avalos, J. (1996) Distribution of seagrasses in the Yucatan Peninsula, Mexico. Bulletin of Marine Science 59: 449-454.

Espinoza-Avalos, J., Hernández-Arana, H.A., ÁlvarezLegorreta, T., Quan-Young, L.I., Oliva-Rivera, J.J., ValdeZHernández, M., Zavalamendoza, A., Cruz-Piñón, G., López, C.Y., Sepúlveda-Lozada, A., Worumference, P., VillegasCastillo, A. And Tussenbroek, B.I.V. (2009) Vegetación acuática sumergida. Pages148-158 in Espinoza-Avalos, J., IsLebe, G. AND Hernández-Arana, H. (Eds) El sistema ecológico de la Bahía de Chetumal / Corozal: costa occidental del Mar Caribe. El Colegio de la Frontera Sur, Chetumal, Quintana Roo, México.

Etheridge, K., Rathbun, G.B., Powell, J.A. and Kochman, H.I. (1985) Consumption of aquatic plants by the West Indian manatee. Journal of Aquatic Plant Management 23: 21-25.

Fitzgerald, A.E. And Waddington, D.C. (1979) Comparison of two methods of fecal analysis of herbivore diet. The Journal of Wildlife Management 43(2): 468-473.

Gales, N., McCauley, R.D., Lanyon, J. And Holley, D. (2004) Change in abundance of dugongs in Shark Bay, Ningaloo and Exmouth Gulf, Western Australia: evidence for large-scale migration. Wildlife Research 31(3): 283-290.

Garin, I., Aldezabal, A., García-González, R. and Aihartza, J.R. (2001) Composición y calidad de la dieta del ciervo (Cervus elaphus L.) en el norte de la Península Ibérica. Animal Biodiversity and Conservation 24(1): 53-63.

Guterres, M.G., Marmontel, M., Ayub, D.M., Singer, R.F. And SINGER, R.B. (2008) Anatomia e morfologia de plantas aquáticas da Amazônia - utilizadas como potencial alimento por peixe-boi amazônico. IDSM, Belém.

HaRTMAN, D.S. (1979) Ecology and behavior of the manatee (Trichechus manatus) in Florida. American Society of Mammalogists. Special Publication No 5. Lawrence, Kans.
HeINSOHN, G.E. AND BIRCH, W.R. (1972) Food and feedings habits of the dugong, Dugong dugon (Erxleben), in Northern Queensland, Australia. Mammalia 36: 414-422.

Heinsohn, G.E. And Spain, A.V. (1974) Effects of a tropical cyclone on littoral and sub-littoral biotic communities and on a population of dugongs (Dugong dugon, Muller). Biological Conservation 6(2): 143-152.

HURST, L.A. AND BECK, C. (1988) Microhistological characteristics of selected aquatic plants of Florida,- with techniques for the study of manatee food habits. U.S. Fish and Wildlife Service. Biological Report 88 (18).

Johnstone, I.M. And Hudston, E.T. (1981) The dugong diet: Mouth sample analysis. Bulletin of Marine Science 31: 681-690.

Langtimm, C.A. And Beck, C.A. (2003) Lower survival probabilities for adult Florida manatees in years with intense coastal storms. Ecological Applications 13(1): 257-268.

Langtimm, C.A., Krohn, M.D., Reid, J.P., Stith, B.M. And BeCK, C.A. (2006) Possible effects of the 2004 and 2005 hurricanes on manatee survival rates and movement. Estuaries and Coasts 29(6A): 1026-1032.

Larkin, I.L.V., Fowler, V.F. AND ReEP, R.L. (2007) Digesta passage rates in the Florida manatee Trichechus manatus latirostris. Zoo Biology 26(6): 503-515.

LedDeR, D.A. (1986) Food habits of the West Indian manatee, Trichechus manatus latirostris, in South Florida. MSc Thesis. University of Miami. Coral Gables, Florida. 62 pp.

LefeBvRE, L.W. AND PowELL, J.A. (1990) Manatee grazing impacts on seagrasses in Hobe Sound and Jupiter Sound in Southeast Florida during the winter of 1988-89. U.S. Fish and Wildlife Report PB90-271883. pp. 36.

Lefebvre, L.W., Marmontel, M., Reid, J.P., Rathbun, G.B. and Domning, D.P. (2001) Distribution, status, and biogeography of the West Indian Manatee. Pags 425-474 in Woods, C.A. AND SERGILE, F.E. (Eds) Biogeography of the West Indies: Patterns and Perspectives. CRC Press, Boca Raton (FL).

Lewis, R.R., Carlton, J.M. and Lombardo, R. (1984) Algal consumption by the manatee (Trichechus manatus l.) in Tampa Bay, Florida. Florida Science 47(3): 187-189.

LOMOLINO, M.V. AND EwEL, K.C. (1984) Digestive efficiencies of the West Indian manatee (Trichechus manatus). Florida Science 47(3): 176-179.

Mangel, M. And Tier, C. (1994) Four facts every conservation biologists should know about persistence. Ecology and Society 75(3): 607-614.

Marsh, H.E., Channells, P.W., Heinsohn, G.E. And Morrisey, J. (1982) Analysis of stomach contents of dugongs from Queensland. Australian Wildlife Research 9: 55-67.

Marsh, H.E., Freeland, W.J., Limpus, C.J. And Reed, C.J. (1986) The stranding of dugongs and sea turtles resulting from Cyclone Kathy, March 1984: A report on the rescue effort and the biological data obtained. Parks and Wildlife Unit. Conservation Commission of the Northern Territory.

MARSH, H.E. (1989) Mass stranding of dugongs by a tropical cyclone in Northern Australia. Marine Mammal Science 5(1): 78-84.

Marshall, C.D., Huth, G.D., Edmonds, V.M., Halin, D.L. And ReeP, R.L. (1998) Prehensile use of perioral bristles during feeding and associated behaviors of the Florida manatee (Trichechus manatus latirostris). Marine Mammal Science 14(2): 274-289. 
Marshall, C.D., Kubilis, P.S., Huth, G.D., Edmonds, V.M., Halin, D.L. AND ReEP, R.L. (2000) Food-handling ability and feeding-cycle length of manatees feeding on several species of aquatic plants. Journal of Mammalogy 81(3): 649-658.

Marshall, C.D., Maeda, H., Inata, M., Furuta, M., Asano, S., RosAs, F.C.W. AND REEP, R.L. (2003) Orofacial morphology and feeding behaviour of the dugong, Amazonian, West African and Antillean manatees (Mammalia:Sirenia): Functional morphology of the muscular-vibrissal complex. Journal of Zoology 259: 245-260.

Mignucci-Giannoni, A.A. And BeCK, C.A. (1998) The diet of the manatee (Trichechus manatus) in Puerto Rico. Marine Mammal Science 14(2): 394-397.

Morales-Vela, B. And Olivera-GómeZ, L.D. (1994) Distribución espacial y estimación poblacional de los manatíes en la Bahía de Chetumal, Quintana Roo, México. Revista de Investigatión Científica 2 (No. Esp. SOMEMMA 1): 27-34.

Morales-Vela, B. (1997) Manatee sanctuary created in Mexico. Sirenews(27): 16.

O'Shea, T.J., Beck, C.A., Bonde, R.K., Kochman, H.I. And Odell, D.K. (1985) An analysis of manatee mortality patterns in Florida, 1976-81. Journal of Wildlife Management 49(1): 1-11.

O'SheA, T.J. And SALisbury, C.A. (1991) Belize, a last stronghold for manatees in the Caribbean. Oryx 25(3): 156-164.

Orozco-Meyer, A. (1995) Colecciones de referencias semipermanente en laminillas de pastos marinos de la Bahía Chetumal, como parte del Proyecto Manat. Práctica Profesional. Instituto Tecnológico de Chetumal. El Colegio de la Frontera Sur, Chetumal, Quintana Roo, México.

PACKARD, J.M. (1984) Impact of manatees Trichechus manatus on seagrass communities in eastern Florida. Acta Zoologica Fennica 172: 21-22.

PREEN, A. (1995) Diet of dugongs: Are they omnivores? Journal of Mammalogy 76(1): 163-171.

Preen, A. And Marsh, H. (1995) Response of dugongs to largescale loss of seagrass from Hervey Bay, Queensland, Australia. Wildlife Research 22(4): 507-519.
Provancha, J.A. and Hall, C.R. (1991) Observations of associations between seagrass beds and manatees in East Central Florida. Biological Sciences 54(2): 87-98.

QuAN-Young, L.I., JimÉnez-Flores, S.G. AND EsPINOZA-Ávalos, J. (2006) Flora béntica y reproducción de las algas Batophora spp. (Chlorophyta: Dasycladaceae) de una laguna costera contaminada (Bahía de Chetumal, México). Revista de Biologia Tropical 54(2): 341-355.

Reich, K.J. And Worthy, G.A.J. (2006) An isotopic assessment of the feeding habits of free-ranging manatees. Marine Ecology Progress Series 322: 303-309.

REYNOLDS III, J.E. AND Rommel, S.A. (1996) Structure and function of the gastrointestinal tract of the Florida manatee, Trichechus manatus latirostris. The Anatomical Record 245(3): 539 - 558.

Ronald, K., Selley, L.J. AND Amoroso, E.C. (1978) Biological Synopsis of the Manatee. IDRC. International Development Research Centre, Otawa, Canada.

Rosito, J.M. And Marchezan, E. (2003) Determinação de descritores foliares para a identificação microhistológica de espécies forrageiras. Acta Scientiarum 25(2): 407-413.

Sepúlveda-Palma, L., Pelliza, A. and Manacorda, M. (2004) La importancia de los tejidos no epidérmicos en el microanálisis de la dieta de herbívoros. Ecología Austral 14(1): 31-38.

SмITH, K.N. (1993) Manatee habitat and human-related threats to seagrass in Florida: A review. Department of Environmental Protection. Division of Marine Resources. Office of Protected Species Management.

SNIPES, R.L. (1984) Anatomy of the cecum of the West Indian manatee, Trichechus manatus (Mammalia, Sirenia). Zoomorphology 104: 67.78.

Spain, A.V. and Heinsohn, G.E. (1973) Cyclone associated feeding changes in the dugong (Mammalia: Sirenia). Mammalia 37(4): 678-680

Tomlinson, P.B. And Cox, P.A. (2000) Systematic and functional anatomy of seedlings in mangrove Rhizophoraceae: vivipary explained? Botanical Journal of the Linnean Society 134(1-2): 215-231. 